\title{
Methodological Proposal of Policies and Procedures for Quality Assurance in Information Systems for Software Development Companies Based on CMMI
}

\author{
Doris Cáliz ${ }^{1 *}$, Gustavo Samaniego ${ }^{2}$, Richard Cáliz ${ }^{2}$ \\ 1 Polytechnic University of Madrid, Department of Languages and Systems and Software Engineering \\ (DLSIIS), Campus of Montegancedo 28660 Boadilla del Monte, Madrid, Spain. \\ 2 FIS Group, Department of Information Systems and Computer Science (DICC), National Polytechnic School, \\ EPN. Ladrón de Guevara E11-25 y Andalucía. Quito, (Ecuador). \\ * Corresponding author. Email: doris.caliz@alumnos.upm.es \\ Manuscript submitted July 10, 2015; accepted December 8, 2015. \\ doi: 10.17706/jsw.11.3.230-241
}

\begin{abstract}
The aim of this work is to make a guide based on Capability Maturity Model Integration (CMMI) that is adapted to the reality of software development companies in Ecuador. The current work initially analyzes a conceptual reference framework with fundamental definitions from CMMI. Then, based on surveys, it presents a study of the current quality situation in software development companies, determining the priority given to the quality of the technological product delivered to the end customer. Subsequently, it proposes a set of policies and procedures based on CMMI for information systems quality control at software development companies. These proposals are present-ed clearly and concisely for each of the processes covered by the Engineering Area of CMMI. Finally, a validation of the applicability of the proposal for a medium-sized, nationally-representative software development company is presented. Additionally, the cost-benefit analysis of the proposal is included to better visualize the investments to be made and their potential benefits.
\end{abstract}

Key words: Quality software, CMMI software development, software quality policy, quality control.

\section{Introduction}

Quality assurance should be carried out in each phase of the software development process. For high quality software, records management documents should be quality products. For this reason, it is vital to clearly define the processes and responsibilities for each activity and their respective reviews [1]. However, the concept of quality software products has not been give this importance in Ecuador. This was determined through the responses of surveys given to the most important software companies in Ecuador. The main reason for the lack of quality software products is most likely the ignorance of the damage that poor quality products cause as opposed to the benefits of establishing processes for the development of organized policies for quality.

\section{Background}

Software quality can be defined as the set of properties that give software the ability to satisfy the explicit and implicit requirements of its user. The quality model ISO/IEC 9126 ISO/IEC 9126 defines the quality of a 
software product in terms of six main features: functionality, reliability, usability, efficiency, maintainability, and portability ISO IEC 9126-1 (2001). By combining these features, evaluation methods can be grouped as follows: inspection methods, methods of inquiry, and empirical methods [2]. Quality assurance methods based on software process improvement models have always been regarded by the software engineering community as one of the main sources of variability in software productivity [3]. This productivity may be positively influenced by disruptive software development methodologies (e.g., lean methods or automated development tools); however, there may also be impending costs [3]. Capability Maturity Model ( Integrations (CMMI) is a model of a maturity improvement process for product development and services. We can see in Figure1. It consists of best practices that address development activities and maintenance which covers the lifecycle of the product. The CMMI-DEV model provides guidance for applying CMMI best practices in a development organization [4].

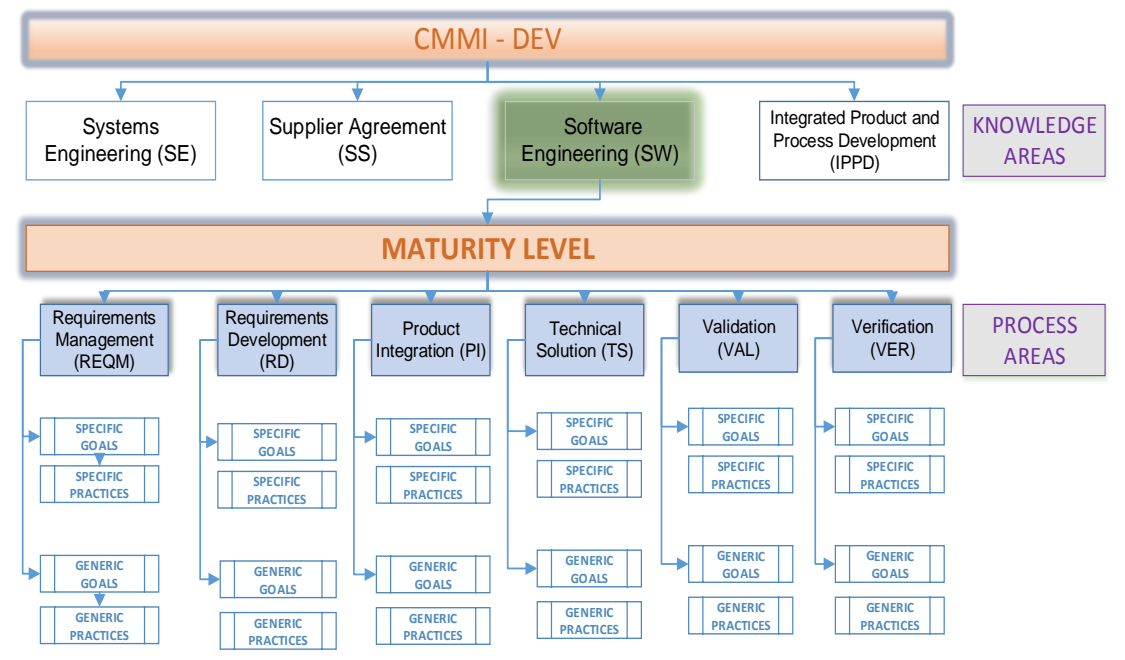

Fig. 1. CMMI scheme.

\subsection{Comparison of Quality Management Models}

An analysis of the different methodologies and models of quality management is performed: ISO 9000 covers a quality aspect that is applicable to anything, it is not limited just to software [2]. ISO 9001: 2008 is a set of social type and organizational rules to improve capabilities and performance. ISO/IEC 15504 with ISO 12207 applies a standard to the evaluation and improvement of the quality of both the development process and in software maintenance. Six Sigma is a process improvement methodology focused on reducing or eliminating the defects or failures in the delivery of a product or service to the customer. TSP is a set of practices for developing quality software products on time and on budget. PSP is used to improve discipline and competencies of an organization. CMMI is a model of evaluation of the processes of an organization. It is a model for the improvement and evaluation of processes of development and for the maintenance and operation of software systems [4]. After analyzing the different methods, it is clear that the model which best meets our needs is CMMI. The detailed analysis can be found in the full thesis of the authors in [5].

\subsection{Analysis of Current Status of Software Development Companies}

Two evaluation surveys were administered to determine the current state of software development companies with regards to quality control. The sample, $n=4$, is properly documented in the thesis. Quality Management System Survey: To understand the degree of quality control of the various processes in 9001: 2000. It has been noted that no part of the survey received more than $45 \%$ of positive answers. While it is 
done in some companies in a rudimentary way, overall there is basically no system management of representative quality. This can be seen in Table 1 and Fig. 2. Generic Quality Control Area Survey: To determine the size of the organization and the quality area. The analysis of the results found $13 \%$ positive answers, which indicates a low percentage of compliance with quality standards.

Table 1. Positives Results of the Quality Management System Survey

\begin{tabular}{lllll}
\hline \hline Area & Company A & Company B & Company C & Company D \\
\hline Main channel Documentation Requirements & 20 & 20 & 40 & 30 \\
Management Responsibility & 25 & 33 & 42 & 25 \\
Resource Management & 33 & 33 & 67 & 33 \\
Product Realization & 44 & 36 & 48 & 40 \\
Measurement, Analysis And Improvement & 12 & 12 & 29 & 29 \\
\hline \hline
\end{tabular}

For the enterprises surveyed, each had less than $1 \%$ of their staff dedicated to software quality control. The lack of dedicated personnel in this area highlights the low importance given to software quality assurance.



Fig. 2. Results of the quality management system survey.



Fig. 3. CMMI vs the proposal.

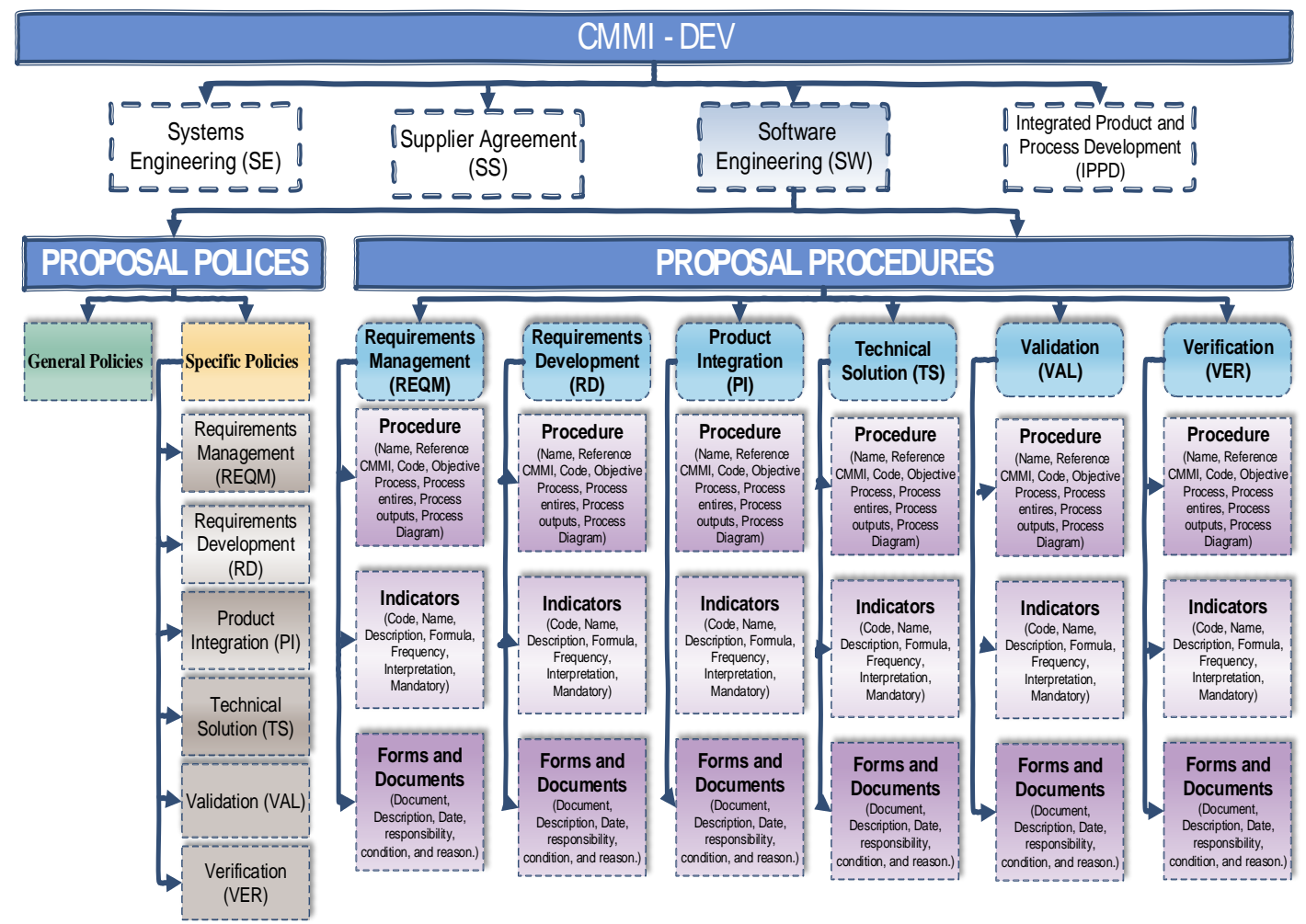

Fig. 4. Proposal. 


\section{Proposal}

After studying the primary methodologies, this research proposes a practical methodology to make a guide based on CMMI that is adapted to the realities of software development companies in Ecuador. The innovative value of this project lies in its methodology, which will allow for quantitative identification of the degree of usability of mobile applications. This includes relevant aspects to be considered when this software is used by the elderly population.

The CMMI-DEV model has four areas of knowledge. Our proposal utilizes the area of software engineering. The proposal is shown in Fig. 4.

This knowledge area has six process areas. Each of these process areas includes: generic goals, specific goals, generic practices, and specific practices. Fig. 5 presents a mode. The proposal is limited to quality control processes in software development, all other process types are outside the scope.

\subsection{Policies, There Are two Types of Policies: General and Specific}

\subsubsection{General policies}

Generic practices are components that are common in all process areas. Table 2 describes the policies that will allow for the adoption of the proposed development companies in the country.

Table 2. General Policies

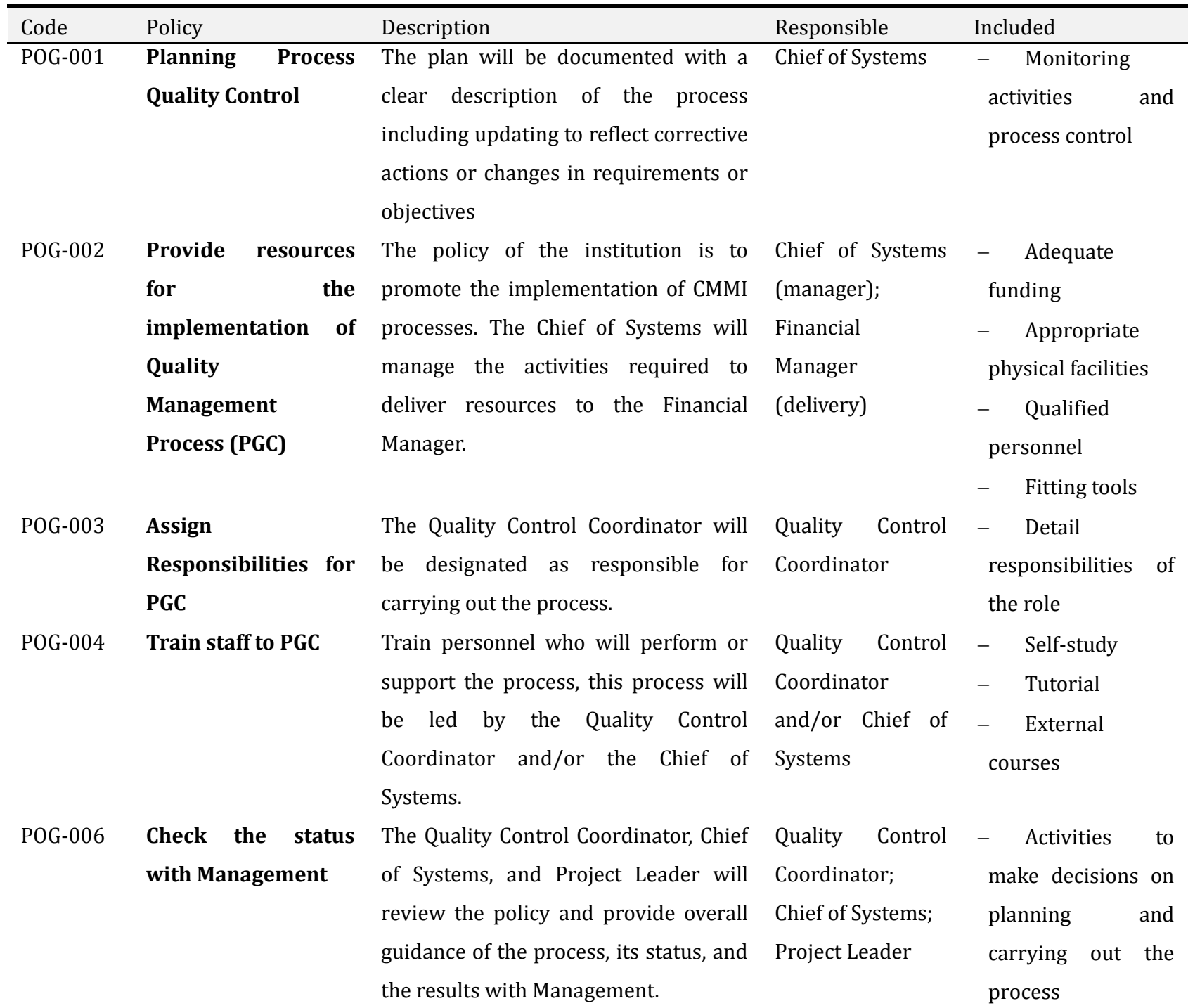


POG-007

Establish a defined process

$\begin{array}{lll}\text { process } & \begin{array}{l}\text { Project Leader will establish and } \\ \text { maintain a description of the process }\end{array} \\ \text { that will be adapted to all standard } \\ \text { POG-008 Collect } \\ \text { improvement } \\ \text { information }\end{array} \quad \begin{aligned} & \text { Quality Control Coordinator will } \\ & \text { collect the relevant information from } \\ & \text { work products, measures, } \\ & \text { measurement results, and information } \\ & \text { to support and improve future } \\ & \text { planning and implementation } \\ & \text { processes. }\end{aligned}$

POG-009

Establish

quantitative targets for the process

P0G-010 Ensure continuous improvement of PGC

process improvements and on

technology.

POG-011 Correct the root The Quality Control Coordinator and causes of problems Chief of Systems will analyze the defects and problems encountered in the process.

POG-012 Constantly
disseminate the
results of the
process

POG-013 Staff specialize in The development company ensures their roles

\subsubsection{Specific policies}

The Quality Control Coordinator will provide monthly reports with

Quality Control

Coordinator;

Chief of Systems

Quality Control
Coordinator Co

Coordinator;

Project Leader

inclusion in the
library

- Establish

quantitative

objectives of the

process

\begin{tabular}{lll} 
Quality Control & - & \multicolumn{1}{c}{ Establish and } \\
Coordinator & maintain & \\
& quantitative & \\
& objectives for \\
& process & \\
& improvement.
\end{tabular}

- Prepare a document with the solutions to be applied to errors

Quality Control - Circulation of Coordinator indicators per project

- Plan staff training

Table 3 describes the specific policies of the six areas in the engineering process category.

Table 3. Specific Policies

\begin{tabular}{lllll}
\hline \hline Area & Code & Policy & Responsible & Process \\
Requirements & POGRE-001 & Policy to understand requirements. All Analyst & GREPR001 \\
Management & & $\begin{array}{l}\text { analysts should have a complete } \\
\text { understanding of the project to be developed } \\
\text { (REQM) }\end{array}$ & \\
\hline \hline
\end{tabular}




\begin{tabular}{|c|c|c|c|c|}
\hline & POGRE-002 & $\begin{array}{l}\text { Policy to obtain commitment requirements. } \\
\text { The requirements to make the development } \\
\text { must be agreed upon and signed between the } \\
\text { parties. }\end{array}$ & Analyst & GREPR002 \\
\hline & POGRE-004 & $\begin{array}{l}\text { Policy to analyze inconsistencies. Any } \\
\text { inconsistency between the requirements and } \\
\text { the products will be documented and analyzed. }\end{array}$ & Project Leader & GREPR005 \\
\hline \multirow[t]{3}{*}{$\begin{array}{l}\text { Requirements } \\
\text { Development } \\
\text { (RD) }\end{array}$} & PODRE-001 & $\begin{array}{l}\text { Policy needs for identification. Any request } \\
\text { will be formally written with enough detail to } \\
\text { continue the development stages. }\end{array}$ & Analyst & DREPR.002 \\
\hline & PODRE-002 & $\begin{array}{l}\text { Formalize requirements. The architect of the } \\
\text { project will support any specific technical need } \\
\text { that deserves to be understood. }\end{array}$ & Architect & DREPR.003 \\
\hline & PODRE-003 & $\begin{array}{l}\text { Policy for Requirements Analysis. } \\
\text { Functional prototypes will be developed to } \\
\text { validate the capture of requirements made by } \\
\text { the equipment system analysis. }\end{array}$ & $\begin{array}{l}\text { Team } \\
\text { Leader }\end{array}$ & DREPR.009 \\
\hline \multirow[t]{3}{*}{$\begin{array}{l}\text { Technical } \\
\text { Solution (TS) }\end{array}$} & POSTE-001 & $\begin{array}{l}\text { Policy for design test case. The modules must } \\
\text { be properly tested by the Programmer before } \\
\text { being sent to the testing group. }\end{array}$ & Programmer & STEPR.008 \\
\hline & POSTE-002 & $\begin{array}{l}\text { Policy for feasibility analysis to make, buy, } \\
\text { or reuse. The decision to buy, reuse, or } \\
\text { develop in complex cases must be supported } \\
\text { by a document containing the selection criteria } \\
\text { and the responsibilities. }\end{array}$ & Project Leader & STEPR.009 \\
\hline & POSTE-003 & $\begin{array}{l}\text { Policy for the selection of solutions. It is the } \\
\text { project architect's responsibility to correct the } \\
\text { selection of technological alternatives and } \\
\text { solutions. }\end{array}$ & Architect & STEPR.005 \\
\hline \multirow[t]{3}{*}{$\begin{array}{l}\text { Product } \\
\text { Integration } \\
\text { (PI) }\end{array}$} & POIPO-001 & $\begin{array}{l}\text { Policy to develop an integration plan. } \\
\text { Integrating products will always be scheduled } \\
\text { by the Project Leader with special care of the } \\
\text { components. }\end{array}$ & Project Leader & IPOPR.001 \\
\hline & POIPO-002 & $\begin{array}{l}\text { Policy to prepare environments. All } \\
\text { environments required for integration will be } \\
\text { managed by the Project Leader and prepared } \\
\text { by the group configuration management } \\
\text { company. }\end{array}$ & Project Leader & IPOPR.004 \\
\hline & POIPO-004 & $\begin{array}{l}\text { Policy for product delivery. The product } \\
\text { delivery should be a formal process, including } \\
\text { a record of delivery and a receipt signed by the } \\
\text { relevant parties. }\end{array}$ & Project Leader & IPOPR.011 \\
\hline \multirow[t]{3}{*}{$\begin{array}{l}\text { Verification } \\
\text { (VER) }\end{array}$} & POVER-001 & $\begin{array}{l}\text { Policy to select work products to check. } \\
\text { Work products will be selected based on their } \\
\text { contribution to meet the objectives and } \\
\text { requirements of the project and determine the } \\
\text { risks. }\end{array}$ & $\begin{array}{l}\text { Quality Control } \\
\text { Coordinator }\end{array}$ & VERPR.001 \\
\hline & POVER-002 & $\begin{array}{l}\text { Policy to establish a verification } \\
\text { environment. A tool for incident tracking } \\
\text { solutions (Mantis Bug Tracker) is established. } \\
\text { This tool will collect and process all incidents } \\
\text { with metrics. }\end{array}$ & $\begin{array}{l}\text { Quality Control } \\
\text { Coordinator }\end{array}$ & VERPR.002 \\
\hline & POVER-003 & $\begin{array}{l}\text { Policy for the corrections plan and settings. } \\
\text { Support and correction cases will not be } \\
\text { addressed outside of the incident tracking tool. }\end{array}$ & $\begin{array}{l}\text { Quality Control } \\
\text { Coordinator }\end{array}$ & VERPR.011 \\
\hline $\begin{array}{l}\text { Validation } \\
\text { (VAL) }\end{array}$ & POVAL-001 & $\begin{array}{l}\text { Policy for validation planning. The plan will } \\
\text { include validation tasks to be performed and } \\
\text { should establish those responsible for fulfilling }\end{array}$ & Project Manager & VALPR.001 \\
\hline
\end{tabular}


each task.

POVAL-002 Policy to select products for validation.

Products and product components will be selected to be validated based on their

Project Manager;

VALPR.002 relationship to the user's needs.

POVAL-003 Policy to define acceptance criteria. Quality Control VALPR.003 Performance metrics of products will be Coordinator defined to determine if they meet or are within the allowed range to be certified.

\subsection{Procedure Definitions}

The procedures are performed based on each of the following process areas: requirements management (REQM), requirements development (RD), technical solution (TS), product integration (PI), verification (VER), and validation (VAL). This summary will only refer to the first area-the requirements management process. All process areas can be analyzed in greater detail in the thesis by the authors [5].

\subsubsection{Requirements management}

\subsubsection{Procedures}

Table 4 describes, in detail, the requirements management procedures.

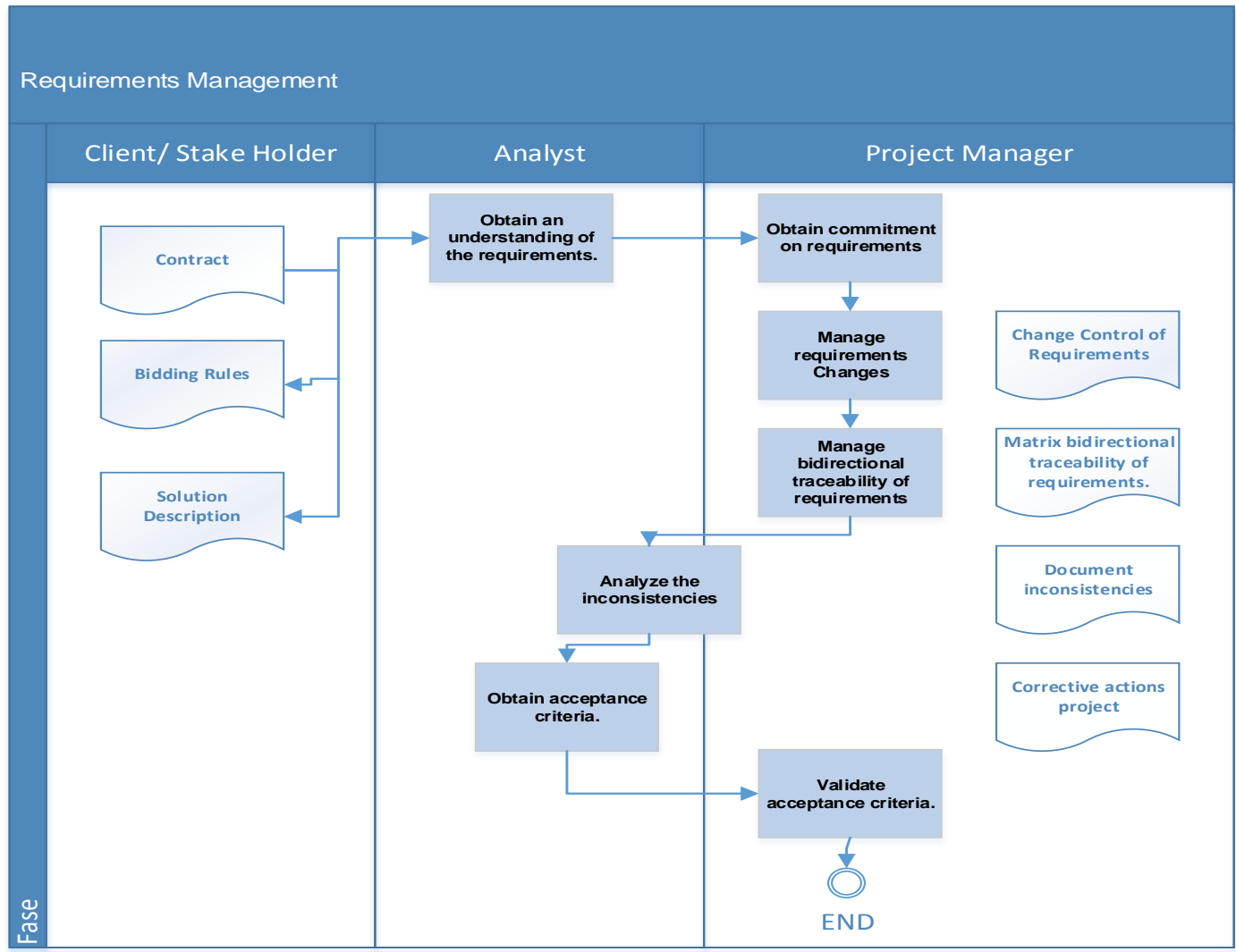

Table 4. Procedure for Requirements Management

\begin{tabular}{ll}
\hline \hline Process Name: & Requirements Management \\
Reference CMMI: & Requirements Management \\
Code & GRE
\end{tabular}




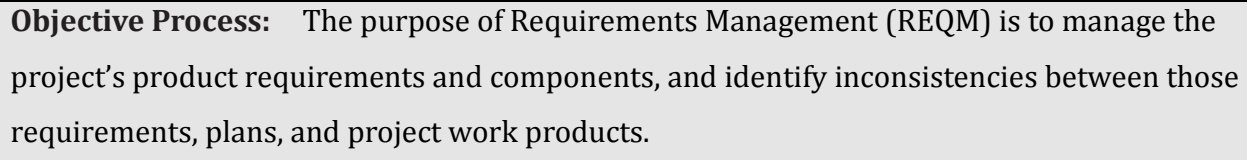

Process Entries

Process Outputs

Process Diagram:
- $\quad$ Customer needs, requirements change needs

- Document inconsistencies, corrective actions for project, matrix bidirectional traceability of requirements, change control requirements.

$\begin{array}{ll}\text { Code } & \text { Name } \\ \text { GREPR.0 } & \text { Obtain an } \\ 01 & \begin{array}{l}\text { understanding of } \\ \text { the requirements. }\end{array} \\ & \\ \text { GREPR. } & \text { Obtain a } \\ 002 & \text { commitment on } \\ & \text { the requirements }\end{array}$

GREPR. Manage the

bidirectional traceability of requirements 005 inconsistencies 003 requirements
GREPR. Analyze the

\section{Description}

Within the development company, the project analyst works to carry out this procedure. The purpose is to develop an understanding of the meaning of the requirements with suppliers. The work products within this procedure are: lists of criteria to distinguish to the requirements providers, criteria for evaluation and acceptance of requirements, analysis of results against criteria, and an agreed upon set of requirements.

When integrated teams are created, the project participants are the integrated teams and their members. Typical work products are: impact evaluations of requirements, and documented commitments of the requirements and their change. Tasks to consider are: assess the impact of requirements on existing commitments, and negotiate and record the commitments.

GREPR. Manage changes to Manage changes to requirements as they evolve during the project. Typical work products are: state of requirements, database requirements, and a database of requirement decisions. Tasks to consider are: document all requirements and changes to the requirements, and evaluate the impact of changes to the requirements.

The intent of this specific practice is to maintain the bidirectional traceability of requirements for each level of product decomposition. Typical work products are: matrix of traceability of requirements, and system of tracking of requirements. Tasks in the procedure are: generate the matrix of traceability of requirements.

Detail the inconsistencies between the requirements, project plans, and work products and then initiate corrective action to resolve them. Typical work products are: documentation of inconsistencies (including sources, conditions, and reasons), and corrective actions. Tasks in this procedure include: review plans, identify the source of the inconsistency and reason, and start corrective actions.

GREPR. Obtain acceptance The analyst of the development company should be able to obtain the 006 criteria. and properly established, complete, consistent, uniquely identified, 
GREPR. Validate acceptance criteria.
The company's development includes an important activity that should be completed by the stakeholder or customer to validate the criteria under which a request will be accepted or denied.

\subsubsection{Indicators}

Table 5 will describe requirements management indicators.

Table 5. Requirements Management Indicators

\begin{tabular}{|c|c|c|c|}
\hline Code & $\begin{array}{l}\text { Indicato } \\
\mathbf{r}\end{array}$ & & Details \\
\hline \multirow[t]{5}{*}{$\begin{array}{l}\text { DREIN. } \\
001\end{array}$} & \multirow{5}{*}{$\begin{array}{l}\text { Percentage } \\
\text { of changes } \\
\text { to } \\
\text { requiremen } \\
\text { ts }\end{array}$} & Description & $\begin{array}{l}\text { Indicates a percentage of changed requirements on total accepted } \\
\text { requirements }\end{array}$ \\
\hline & & Formula & $\begin{array}{l}\frac{N R C}{N R T} * 100 \% \\
\text { NRC: number of requirements with changes, NRT: number of total } \\
\text { requirements }\end{array}$ \\
\hline & & Frequency & $\begin{array}{l}\text { Used as the metric for when the project ends, or monthly, to determine } \\
\text { the punctuality of the project, considering all of the projects. }\end{array}$ \\
\hline & & $\begin{array}{l}\text { Interpretatio } \\
\text { n }\end{array}$ & $\begin{array}{l}\text { It is desirable for a development company to have a value of } 0 \% \text {, which } \\
\text { indicates that the requirements have been well-understood since the } \\
\text { beginning. }\end{array}$ \\
\hline & & Mandatory & YES \\
\hline \multirow[t]{4}{*}{$\begin{array}{l}\text { DREIN. } \\
002\end{array}$} & \multirow{4}{*}{$\begin{array}{l}\text { Deviation in } \\
\text { compliance } \\
\text { with project } \\
\text { plans }\end{array}$} & Description & $\begin{array}{l}\text { Indicates a percentage of the planned value of progress in the } \\
\text { construction of the requirements against the actual value. }\end{array}$ \\
\hline & & Formula & $\begin{array}{l}\frac{T R P}{T P P} * 100 \% \\
\text { TRP }=\text { real time for the project, } \mathrm{TPP}=\text { planned time for the project }\end{array}$ \\
\hline & & $\begin{array}{l}\text { Frequency } \\
\text { Interpretatio } \\
\text { n }\end{array}$ & $\begin{array}{l}\text { Monthly } \\
\text { It is desirable that this value is a low or negative rate which would } \\
\text { indicate that the project is completed correctly and on- or ahead of } \\
\text { time. }\end{array}$ \\
\hline & & Mandatory & 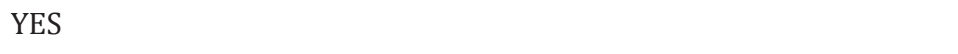 \\
\hline \multirow[t]{5}{*}{$\begin{array}{l}\text { DREIN. } \\
003\end{array}$} & $\begin{array}{l}\text { Corrective } \\
\text { actions }\end{array}$ & Description & $\begin{array}{l}\text { Indicates a value to quantitatively know how many corrective actions } \\
\text { were given }\end{array}$ \\
\hline & project & Formula & $\mathrm{N}=$ number of remedial actions generated by the project. \\
\hline & & Frequency & Monthly \\
\hline & & $\begin{array}{l}\text { Interpretatio } \\
\text { n }\end{array}$ & $\begin{array}{l}\text { It is desirable that this value is as low as possible. A larger value will } \\
\text { reflect mismanagement at the requirements level. Comparatively, in } \\
\text { several measures this value tends to decrease. }\end{array}$ \\
\hline & & Mandatory & 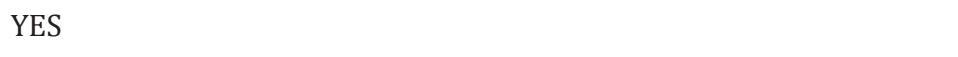 \\
\hline \multirow{2}{*}{$\begin{array}{l}\text { DREIN. } \\
004\end{array}$} & Number of & Description & Indicates a quantitative value to quantitatively of how many \\
\hline & $\begin{array}{l}\text { inconsisten } \\
\text { cies found }\end{array}$ & Formula & $\begin{array}{l}\text { inconsistencies related to the requirements exist. } \\
\mathrm{N}=\text { number of inconsistencies generated by the project }\end{array}$ \\
\hline
\end{tabular}




\begin{tabular}{|c|c|c|}
\hline \multirow{4}{*}{$\begin{array}{l}\text { in the } \\
\text { requiremen } \\
\text { ts }\end{array}$} & Frequency & Monthly \\
\hline & Interpretatio & It is desirable that this value is as low as possible. A larger value will \\
\hline & n & $\begin{array}{l}\text { reflect mismanagement at the requirements level. Comparatively, in } \\
\text { several measures this value tends to decrease. }\end{array}$ \\
\hline & Mandatory & YES \\
\hline
\end{tabular}

\subsubsection{Forms and documents of management requirements}

Table 6 describes the forms and documents of Management Requirements.

Table 6. Forms and Documents of Management Requirements

\begin{tabular}{|c|c|}
\hline Document & Description \\
\hline Document & This document should include a complete record for each inconsistency found that includes: • \\
\hline inconsistencies & Date, responsibility, sources, condition, and reason. \\
\hline $\begin{array}{l}\text { Corrective actions } \\
\text { project }\end{array}$ & $\begin{array}{l}\text { This document provides a mechanism for monitoring and maintaining an inventory of } \\
\text { corrective actions taken by the project. Each project should have a complete record that } \\
\text { includes: • Date, project, corrective action, effect desired, effect achieved. }\end{array}$ \\
\hline $\begin{array}{l}\text { Matrix } \\
\text { bidirectional } \\
\text { traceability of } \\
\text { requirements }\end{array}$ & $\begin{array}{l}\text { Each project should have a matrix which, for each requirement, includes: • Responsibility for } \\
\text { the requirement, who did the implementation, function module, testing the requirement, and } \\
\text { user acceptance. }\end{array}$ \\
\hline $\begin{array}{l}\text { Change control of } \\
\text { requirements }\end{array}$ & $\begin{array}{l}\text { Change controls must be agreed upon and signed by the relevant parties and should include: } \\
\text { - Who requested the change, acceptance, description of the change, affected modules, } \\
\text { monitoring, and control. }\end{array}$ \\
\hline
\end{tabular}

\section{Feasibility Analysis}

A case study was performed on a software development company with about 700 employees in Ecuador. The feasibility of applying this proposal at the economic, technical, operational, and organizational levels is analyzed. Economic feasibility: An estimation (NPV, IRR, PRI) was made and the results show that the proposal is feasible from an economic standpoint. They also indicate a strong predominance of the benefits against the costs. Technical Feasibility: The results of the survey appreciate that $72 \%$ of the responses obtained were positive and therefore indicate feasibility in this area. Organizational Feasibility: The equivalence between the roles of the Research and Development Company case study and the roles that were raised in the proposal is detailed. Equivalence was positive. Operational Feasibility: A survey was administered to the Area Manager of the technology companies. The results of the survey were $98 \%$ positive responses, which indicates feasibility in this area.

\section{Conclusions}

The objectives of this project were covered in full and created a document that proposes a simplified guide for quality management of software development through a set of processes, policies, and practical procedures companies can implement. Following this guide can improve the quality of software products the companies provide. This approach supports goal-setting and prioritization in process improvements for the development of software products which directly improve the quality of products. The goal is to create a work environment where doing things correctly the first time is the objective and where quality is designed and integrated into each activity rather than inspected after products are made. 


\section{Recommendations}

The realities of each software development company are different. We recommend using the principles of quality control when starting a project to implement a proposed quality management as presented in this thesis. In this way, due to economies of scale, it would generate an increase in economic, technical, and operational feasibility to obtain the results and expected benefits. Constant monitoring for policy compliance and appropriate use should be done and internal staff should be trained.

\section{Future Work}

The proposal was validated through a case study in one of the most important software development companies in Ecuador. The feasibility assessment was conducted at the economic-, technical-, operational-, and organizational-levels. The results were favorable to our proposal. Based on this research, future work may consider the real implementation in a software development company and analyze the benefits this methodology has provided since the start of use through the completion of the project.

\section{References}

[1] Ejaz, R., Nazmeen, M., \& Zafar, M. A quality assurance model for analysis phase. Proceedings of the 2010 Natl. Softw. Eng. Conf. - NSEC '10 (pp. 1-4).

[2] Lavallée, M., \& Robillard, P. N. (2011). Do software process improvements lead to ISO 9126 architectural quality factor improvement. Proceedings of the 8th Int. Work. Softw. Qual. WoSQ 11 (pp. 11-17).

[3] Duarte, C. H. C. (2014). On the relationship between quality assurance and productivity in software companies. Proceedings of the 2nd Int. Work. Conduct. Empir. Stud. Ind. - CESI 2014 (pp. 31-38).

[4] Desarrollo, C. (2010). CMMI ® para desarrollo, versión 1.3. C. Para Dsarrolo, Version 1.3, 23.

[5] Cñaliz, D., Terán, C., Samaniego, G., Cáliz, R. (2011). Desarrollo de una propuesta de políticas y procedimientos para el control de calidad de sistemas de información en empresas de desarrollo de Software basado en cmmi. Tesisf. D. E. I. D. E. Sistemas, Escuela Politécnica Nacional.

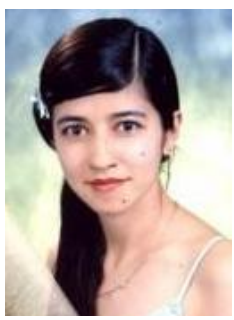

Doris Cruz Caliz Ramos received her master in management of information technology and communications from National Polytechnic School Ecuador from 2008 to 2012.

She is in a International Leadership Training, Germany, from 2011 to 2012. She is a $\mathrm{PhD}$ Student in Polytechnic School Madrid since 2013.

She is a academic visitor in Middlesex University London since 2015.

She is a professional in National Institute of Public Procurement in 2008-2009. And she is the head of the Quality Control Software in Cobiscorp Company from 2009 to 2011.



Cesar Gustavo Samaniego Burbano is a professor of the National Polytechnic School of Ecuador, a member of the Department of Information and Computer Science "DICC" School of Systems Engineering. Quito Ecuador.

$\mathrm{He}$ is a electronics and telecommunications engineer at National Polytechnic School Ecuador.

He received his master of computer science and informatics from National Polytechnic

School Ecuador

He is a learning expert in Processes National Polytechnic School Ecuador. His research interests are in las 
emerging technologies, e-learning, TICs, management.

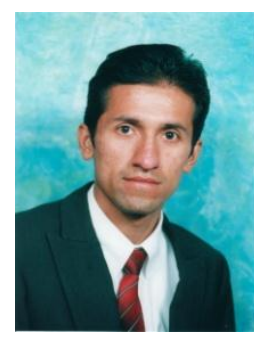

Richarth Harold Caliz Ramos received his master in management of information technology and communications from National Polytechnic School (EPN), Quito, Ecuador from 2008 to 2010 .

He has worked in telecommunications and electronics engineering from National Polytechnic School (EPN), Quito, Ecuador from 1995 to 2002.

He worked as a analyst access network management in Andinatel S. A., Quito, Ecuador from 2003 to 2005. He is the head of management network access Dslam in Andinatel S. A., Quito, Ecuador from 2005 to 2008. 